\title{
Gender-neutral Succession Law in Norway - A Long and Winding Road
}

John Asland

Abstract

This article describes and analyses the process leading up to equal inheritance rights for male and female heirs in Norway and the counter-measures taken in the Norwegian Inheritance Act of 1854 and later as a consequence of the act, especially regarding freedom of testation and allodial rights.

\section{Introduction}

In 2009, a transitional provision in the Norwegian Allodial Rights Act was repealed. ${ }^{1}$ The transitional provision in the act from 1974 said that the gender-neutral regulations on the priority of those entitled to allodial rights - regulations that were introduced in 1974 - did not apply to those who were born or adopted before 1 January 1965 . On the surface, this could seem like a technical adjustment, but actually this minor amendment marked the end of an almost 200-year-long struggle for equal inheritance rights for men and women. The first milestone was the Inheritance Act of 1854 introducing equal inheritance shares for male and female heirs. The second milestone was the Allodial Rights Act of 1974 introducing genderneutral allodial rights. The last milestone was the repeal of the transitional provisions in 2009. In this article, I will describe and analyse this almost 200-year-long process and the

\footnotetext{
${ }^{1}$ Act 19 June 2009, no. 98.
} 
underlying tensions between the proponents and opponents of gender-neutral inheritance rights in general, and especially concerning agricultural property.

The Allodial Rights Act regulates the allodial right (odelsrett), which is an old Norwegian right to reclaim agricultural property classified as allodial property (odelsjord) when such property is transferred, and the residence right (åsetesrett), which is a priority right for the eldest child of the former owner of an allodial property to take over this property on favourable terms (due to fair assessment). These rights have strong traditions in Norwegian culture, and they are even protected in the Norwegian Constitution of 1814:

Allodial right and the right of primogeniture shall not be abolished. The specific conditions under which these rights shall continue for the greatest benefit of the state and to the best advantage of the rural population shall be determined by the first or second subsequent Storting. ${ }^{2}$

An Allodial Rights Act was enacted in 1821. It replaced old provisions on such rights in King Christian V's Norwegian Law Code of 1687. The act of 1821, with some amendments, served until it was replaced by the present Allodial Rights Act of $1974 .^{3}$

The issue of gender-neutrality in inheritance can be traced back to the discussion leading up to the Norwegian Inheritance Act of 1854. The main question in this discussion was whether or not there should be equal inheritance shares for male and female heirs. ${ }^{4}$

\footnotetext{
2 The Norwegian Constitution of 17 May 1814, section 117 (originally section 107).

${ }^{3}$ Allodial Rights Act of 28 June 1974, no. 58.

${ }^{4}$ See Kari Sørsdal, Fra Broderlodd til 'billig taxt' (1854-1863) (Oslo: Institutt for privatrett, University of Oslo, 1980).
} 
Until 1854, Norwegian inheritance law was mainly based on provisions in King Christian V's Norwegian Law Code of 1687. The general principle on the division between male and female heirs was laid down in The Norwegian Law Code of 1687, 5-2-29: "In all Successions a Male Heirs have double what a Female has". ${ }^{5}$ According to this provision, the brother's share was twice the size of the sister's share.

The demand for equal inheritance shares for male and female heirs was an international trend in the wake of the French Revolution. It had been implemented in the European civil codes from the 1790s onwards: the Prussian Civil Code (1794), the French Civil Code (1804), the Austrian Civil Code (1811) and the Dutch Civil Code (1826). It was even implemented in the Swedish Inheritance Code in $1845 .{ }^{6}$ By the middle of the nineteenth century, Denmark and Norway were the only Western European countries that applied unequal inheritance shares for male and female heirs. In Denmark, equal inheritance shares were implemented in the collateral lines in 1845 . However, the principle of double shares for male descendants still remained, as equal inheritance shares for sons and daughters were not implemented in Denmark until $1857 .^{7}$

In the Norwegian parliamentary discussion in the 1840s and 1850s, almost everybody agreed that the principles of equal shares were just and reasonable in their nature. There was no discussion about whether or not this principle should be applied in the collateral lines. Neither was there any discussion on the issue of equal inheritance rights between mothers and

\footnotetext{
${ }^{5}$ The grammatically incorrect English wording used in this article is quoted from The Danish laws or the Code of Christian V. Translated for the Use of the English Inhabitants of the Danish settlements in America (London, 1756). The inheritance provisions in Norwegian Law Code of 1687 were largely based on the inheritance provisions in King Christian V's Danish Law Code. The provision in Norwegian Law Code of 1687, 5-2-29 is identical to 5-2-29 in the Danish Law Code.

${ }^{6}$ See Commission til at udarbeide Udkast til en Lov om Arveretten m.v. (1846), "Angaaende naadigst Proposition til Norges Riges Storthing betræffende Udfærdigelse af en Lov om Arv. Underdanigst Indstilling fra den til at udarbeide Udkast til en Lov om Arveretten m.v. ved Resolution af 7de Februar 1846 nedsatte Commission" (Christiania, 1847). [Draft from the Inheritance Act Commission, submitted to Parliament, 11 June 1847], hereafter referred to Draft 1847 p. 20-21.

${ }^{7}$ For the Danish debate, see Helle Vogt, “"Thi Intet er naturligere og retfærdigere end Qvindekjønnets lige Arveret med Mandskjønnet'," Tidsskrift for rettsvitenskap 122 (2009): 647-74.
} 
fathers when they had lost a child. The opponents to equal inheritance rights in the descendant line were also in favour of increased freedom of testation, so that parents could provide equal inheritance rights for all their children through a will, irrespective of gender. On the other hand, proponents were to some extent also in favour of increased freedom of testation and transitional provisions. In the end, it came down to the question of who should have the burden of testament - those who were in favour of equal inheritance rights or those who were in favour of the old system.

The discussions on equal inheritance rights took place before Norway had a parliamentarian system with political parties. However, it is possible to place most of the opponents and proponents of equal inheritance rights on a right and left scale. Most of the proponents of equal rights were liberal middle-class Members of Parliament employed in the private sector, like the lawyer Johan Sverdrup ${ }^{8}$ and the farmers Ole Gabriel Ueland ${ }^{9}$ and Søren Jaabak. ${ }^{10}$ Johan Sverdrup founded the liberal party Venstre (left) in 1884. Most of the opponents to equal rights were government officers, like the law professor Anton Martin

\footnotetext{
${ }^{8}$ Johan Sverdrup (1816-1892) was a lawyer and politician from Tønsberg. He became a Member of Parliament in 1850. He was a political radical and became one of the leaders on the left side of Norwegian politics. He became the first leader of the liberal party Venstre (left) in 1884 and became Prime Minister the very same year after the breakthrough of the parliamentary system. Source: Per Fuglum, "Johan Sverdrup," Norsk biografisk leksikon (www.snl.no).

${ }^{9}$ Ole Gabriel Ueland (1799-1870) was a farmer and politician from Dalane on the south-western coast of Norway. He belonged to the leading opposition politicians from the 1830s. He was a spokesman for the underprivileged and for the rural areas of Norway. He served as a Member of Parliament from 1833 until his death. Source: Åsmund Svendsen, "Ole Gabriel Ueland," Norsk biografisk leksikon (www.snl.no). ${ }^{10}$ Søren Jaaback (1814-1894) was a farmer and politician from Mandal on the southern coast of Norway. He served as a Member of Parliament from 1845 to 1891 - nobody has ever served for a longer period. Together with Ueland, Jaabæk was a frontrunner in the 'farmer opposition'. He was a democratic radical and an economic liberal. He was one of the founders of the liberal party Venstre (left). Source: Bjørn Slettan, "Søren Jaabæk," Norsk biografisk leksikon (www.snl.no).
} 
Schweigaard ${ }^{11}$ and the customs inspector and previous provincial governor Jens Schydtz, ${ }^{12}$ or aristocrats, like the leader of the Norwegian cabinet, the viceroy Severin Løvenskiold. ${ }^{13}$ This group of conservatives later founded the party Høyre (right) in 1884.

As will be seen from the passages below, the discussion was not merely a discussion between defendants of conservative family values on the one hand, and proponents of women's liberation and equal rights on the other hand. It was indeed also to a large extent a discussion of what kind of legislation could best provide for the needs of society as a whole utilitarianism. And it was a discussion between those who spoke for an unlimited freedom of testation - market liberals - and those who argued for limitations of freedom of testation in order to secure the family - social liberals.

\section{The First Proposals from Parliament}

\section{Under the Norwegian Constitution of 1814, legislative power was assigned to Parliament}

(Stortinget) ${ }^{14}$ As early as the first assembly of the Norwegian parliament in $1815,{ }^{15}$ there was

\footnotetext{
${ }^{11}$ Anton Martin Schweigaard (1808-1870) was a lawyer, economist and politician. He was one of the most important intellectuals and statesmen of the nineteenth century. He graduated from the Royal Frederik's University in Christiania (Oslo) in 1832 and became professor of law, social economy and statistics in 1840. Schweigaard was a member of parliament from 1842 to 1869 . As a lawyer, economist and politician, his ideology was utilitarianism. He was an economic liberalist, but his moral views were more conservative. He rejected natural law. Schweigaard was never a member of the cabinet. He served as a member of parliament, while his close friend Frederik Stang served in the cabinet. Source: Øystein Sørensen, "Anton Martin Schweigaard," Norsk biografisk leksikon (www.snl.no).

12 Jens Schydtz (1792-1859) was born in Copenhagen, but he later moved to Bergen. He was educated as a lawyer and served as a judge, later as County Governor and customs inspector and provincial governor. He was a Member of Parliament from 1833 to 1859. Source: Tallak Lindstøl, Stortinget og Statsraadet 1814-1914, (Kristiania: Steen'ske bogtrykkeri, 1914), 775-76.

${ }^{13}$ Severin Løvenskiold (1777-1856) belonged to one of the last noble families in Norway. He was educated as a lawyer in Copenhagen and studied geology in Saxony and Silesia. Ha had several high positions in the DanishNorwegian government before he moved back to Norway in 1802 to take over his father's ironworks. He was appointed Provincial Governor in 1803 and received the title Chamberlain in 1804. In 1814, he took part in the constitutional assembly at Eidsvoll, although he despised popular sovereignty. He was Viceroy in Norway from 1841 until he died in 1856. His conservatism led to conflicts with the more liberal parliament. He advised the king not to sanction parliament decisions, such as letting Jews enter Norway, railroads, expanded voting rights and, of course, equal inheritance rights for women. Source: Tore Pryser, "Severin Løvenskiold," Norsk biografisk leksikon (www.snl.no).

${ }^{14}$ See the Norwegian Constitution of 17 May 1814, section 75.

15 The Storting assembled every third year from 1814 to 1871 .
} 
a proposal from Consul Johannes Thrane ${ }^{16}$ on "equal inheritance shares for brothers and sisters after their parents", that is, equal inheritance rights in the descendant line. The proposal from Thrane was discussed in the parliamentary Committee for Judicial Affairs on 6

September 1815. The committee did not totally reject the proposal, but it found that the issue was not ready for parliamentary discussions at the time. It should be forwarded to the commission that was established to execute the obligation to publish a new civil code in section 94 of the Constitution. ${ }^{17}$

However, work with a new civil code progressed very slowly. Many people were impatient and argued for amendments to the inheritance legislation, regardless of when and if a new civil code was completed. Various proposals on equal inheritance rights from Members of Parliament were submitted at the sessions of Parliament in 1830, 1833, 1836 and 1842. However, none of these proposals led to any legislative decisions from the Parliament. ${ }^{18}$

In 1830, it was proposed that persons of both genders should have equal inheritance rights unless otherwise decided by will. ${ }^{19}$ In 1833 , there was a new proposal that women should take equal shares with men in all matters of succession, and that women by the age of 18 should achieve the same rights as men who have not reached their full age of capacity. This proposal, which in addition to proposing equal rights between male and female heirs would also increase the legal capacity of women, was forwarded to the Committee for Judicial

\footnotetext{
${ }^{16}$ Johannes Thrane (1779-1841) was a businessman and politician from Christiania (Oslo). He was American Vice Consul in Christiania. Source: Lindstøl, Stortinget og Statsraadet.

${ }^{17}$ Hilde Sandvik and Dag Michalsen, Kodifikasjon og konstitusjon (Oslo: Pax Forlag, 2013).

${ }^{18}$ Indstill. O. no. 15. 1854.

19 Stortingsforhandlingene for mars 1830, p. 269. [This isn't enough information to find this source with only the information given here and in your bibliography, and the same is true for all subsequent references to this source. Here, did you mean this source?: "Forslag fra Repr. Øvern ang. Kvindes Arveret lige med Mands, og at Kvinde ved fyldte 18 Aar maa sættes i Klasse med mindreaarig Mand...." If so, you need to state this somewhere, or at least give more information than just a page number. If not, you need to give more information that will allow your reader to search for the document / source. Or even better, give the url of the document on the website after you search and find it.]
} 
Affairs. However, no decision was taken on the matter. ${ }^{20}$ The 1833 proposal was repeated in 1836 , this time with a concrete wording of the proposed legal text. The proposal of 1836 was forwarded to the Committee for Judicial Affairs, but was never subject to discussions in the Parliament. ${ }^{21}$ In 1842 , the proposals from 1833 and 1836 were repeated. In the 1842 session, there were two similar proposals on equal inheritance rights for male and female heirs. ${ }^{22}$ Neither of these proposals led to further discussions in Parliament. Even if there were voices advocating equal inheritance shares in the 1820 s and 1830 s, the failure of their efforts indicates that the vast majority of the members of Parliament must have been more conservative - or at least not sufficiently interested in the topic as to prioritize it in the legislative process.

\section{The 1845 Proposal and the Parliament's Request to the Cabinet}

It was not until the parliamentary session in 1845 that there was any progress in the process. Three proposals on equal inheritance rights were submitted. ${ }^{23}$ Because of the massive stream of proposals from the Members of Parliament, a parliamentary decision of 2 September 1845 was taken, requesting the Cabinet to draft a bill for a new inheritance act.

"The Cabinet is requested to take all necessary steps to propose to the next Storting a bill to a new inheritance act and other parts of the civil law that are so closely connected to inheritance law that they should be subject to collective processing." ${ }^{24}$ Attached to the request was the proposal from the Parliament's Committee for Judicial Affairs on equal inheritance rights for men and women. Principally, the Committee for Judicial Affairs would dismiss the

\footnotetext{
${ }^{20}$ Stortingsforhandlingene for mars 1833, p. 384.

${ }^{21}$ Stortingsforhandlingene for mars 1836, p. 370.

${ }^{22}$ Stortingsforhandlingene for mars 1842, pp. 126 and 127.

${ }^{23}$ Stortingsforhandlingene for 1845, 7. Del, pp. 49-50 and 355-57.

${ }^{24}$ Stortingsforhandlingene for 1845, 9. Del, p. 257.
} 
proposals, and see this question in the light of a broader revision of the inheritance law and of civil law in general. ${ }^{25}$ However, the committee of judicial affairs discussed the matter quite thoroughly. The discussion in the attachment to the committee's proposal provides a good summary of the leading for and against arguments on the matter of equal inheritance shares. It may also be seen as the mandate on which the expert committee that later was given the assignment to draft a new inheritance act based its proposals. I therefore elaborate quite thoroughly on the committee's viewpoints.

The starting point of the committee was that, merely looking at natural law as a basis for succession rights, there was no doubt that men and woman should be placed on an equal footing, and that the difference between the genders should not be used as justification for different inheritance shares. ${ }^{26}$ The committee stated that there was no general reason to presume that parents have more affection for their sons than for their daughters, and thereby wish to bequeath sons with a greater inheritance share. It was further argued that the need of inheritance is not regularly greater among sons than among daughters. ${ }^{27}$

The committee also focused on the importance of keeping family property undivided. The reason for the gender-based unequal treatment of inheritance rights both in contemporary law and in ancient law was to keep real estate within the family by transferring it undivided to the heir, who was holder of the residence right. ${ }^{28}$ It was argued that within certain limits it is desirable to prevent parcelling of real estate and thereby diminishing the economic strength of the families. Consequently, it was understandable that the inheritance regulations were to some extent coloured by such considerations:

\footnotetext{
25 Stortingsforhandlingene for 1845, 7. Del, p. 357.

${ }^{26}$ Stortingsforhandlingene for 1845, 7. Del, p. 355.

${ }^{27}$ Stortingsforhandlingene for 1845, 7. Del, p. 355.

${ }^{28}$ Stortingsforhandlingene for 1845, 7. Del, p. 356.
} 
It is obvious that the co-heirs' inheritance claims contributes to real estate constantly being encumbered with new debts, and being divided into parcels, since it is a rarity that the deceased possessed enough property in addition to the real estate, to fully satisfy the co-heirs. Thus, the holder of the residence right has to choose between division of the estate or encumbering it with debt. ${ }^{29}$

The committee explained that in order to prevent this result, many countries had gone so far as to exclude specific real property from the regular succession rules, and allowed its transference undivided to one entitled heir without consideration for the other heirs. Such legislative means had previously been used even in Norway through legislation on fiefs (len) and family seats (stamhus). The committee found such legislation unjust and aristocratic. Nevertheless, the committee argued that the regulations in the Allodial Rights Act were insufficient to keep sustainable agricultural units undivided. The Allodial Rights Act, section 14, provided the father a right to divide the odel estate between his children, on the condition that the estate could provide for several families. Section 19 of the act prescribed that real estate should be taxed at its full value, without any mark down to the benefit of the first ranked right-holder of allodial right or residence right. The committee argued that these regulations had contributed substantially to parcelling real estate into "far too small units unable to bread-feed a family and also encumbered in debt to an extent that the property cannot be properly run" ${ }^{30}$ If the inheritance share of sisters was to be put on equal basis with the inheritance share of sons, without taking any precautions in favour of the sons, as a

\footnotetext{
${ }^{29}$ Stortingsforhandlingene for 1845, 7. Del, p. 356.
}

${ }^{30}$ Stortingsforhandlingene for 1845, 7. Del, p. 356. 
consequence, this would make it even harder than at present for the oldest son to buy out his co-heirs. ${ }^{31}$

The committee did not conclude that one should give up equal inheritance rights for women and men to satisfy the interests of holders of the residence right. But it argued that equal inheritance rights would lead to unfavourable results, and that it should not be made applicable unless other adjustments to the legislation were made. The counter-measures were not described in detail, but it was suggested that the holder of the residence right could be offered a larger share than his co-heirs or granted a mark down of the taxation sum. Another possibility was to grant the testator a wider freedom of testation. It was presumed that increased freedom of testation in many cases would be used to benefit the holder of the residence right, as, when the circumstances demanded, the testator would bequeath the holder of the residence right with a substantial share. ${ }^{32}$

It is clear from the passages from the Committee for Judicial Affairs that there was a tension between, on the one hand, the starting point in natural law that all children ought to be treated on an equal basis and, on the other hand, agricultural and business policy considerations in order to prevent splitting up agricultural estates and businesses. This tension between the principle of equality and pragmatic economic arguments characterized the further discussion on equal inheritance rights for men and women. There was reluctance to equalization unless concessions were given in the other direction, like more favourable terms for the holder of the residence right to take over agricultural estates or increased freedom of testation. Even though natural law and pragmatic business policy considerations were the main arguments, the committee's letter was not free from stereotypical prejudices towards women (and men). The transmittal letter from the committee can be seen as a clear

\footnotetext{
${ }^{31}$ Stortingsforhandlingene for 1845, 7. Del, p. 356.

${ }^{32}$ Stortingsforhandlingene for 1845, 7. Del, p. 356.
} 
compromise between a wish to enable equal rights on the one hand, and a wish to strengthen the opportunities for the oldest son to keep family property undivided on the other.

\section{The Inheritance Law Commission}

On 7 February 1846, the government appointed a commission to draft a bill to an act on inheritance and other legislative amendments necessary in connection with such an act. ${ }^{33}$ The members of the commission were Supreme Court Judge Peder Carl Lasson, ${ }^{34}$ and the two assistant professors Georg Frederik Hallager ${ }^{35}$ and Petter Jonas Collet. ${ }^{36}$ The commission was given a deadline to submit its proposal by the end of July 1847, but the efficient commission delivered it on 11 June. The commission work was done in addition to the members' regular work in the Supreme Court and at the university. ${ }^{37}$

The commission referred to their most important sources of inspiration in their transmittal letter to the government. In addition to keep to existing Norwegian law when possible, the commission emphasized the Danish Inheritance Decree of 1845 and the 1846 draft to a New Norwegian Civil Code by Supreme Court Justice Claus Winter Hjelm. ${ }^{38}$

\footnotetext{
${ }^{33}$ Draft 18471.

${ }^{34}$ Peder Carl Lasson (1798-1873) was a lawyer from Asker in Akershus. He became a Supreme Court Judge in 1837 and became the Chief Justice of the Supreme Court in 1855. He served as Chief Justice until he died. No one has held this position as long as Lasson. He was member of various law commissions and he wrote several legal essays. Lasson was a member of the Norwegian Academy of Science and Letters and honorary doctor of the University of Lund in Sweden. He was brother-in-law to Claus Winter Hjelm and grandfather to the famous painter Oda Lasson - who was married to the even more famous painter Christian Krohg. Source: Jon Gunnar Arntzen, "P C Lasson," Norsk biografisk leksikon (www.snl.no).

${ }^{35}$ Georg Frederik Hallager (1816-1876) was born in Copenhagen but moved to Norway in 1827. He became a professor in 1847 and Supreme Court judge in 1864. He wrote substantive works on the law of obligations, law of succession and maritime law. Source: Unknown author, "Georg Frederik Hallager," Store norske leksikon (www.snl.no).

${ }^{36}$ Peter Jonas Collett (1813-1851) was a lawyer from Huseby in Lier near Drammen. He became a professor in 1848. He wrote substantive works on the law of persons and family law. Collet was married to the first female novelist, Camilla Collet (born Wergeland). Source: Sigurd Aa. Arnes, “Jonas Collett - 2," Norsk biografisk leksikon (www.snl.no).

${ }^{37}$ Draft 18471.

${ }^{38}$ Claus Winter Hjelm (1797-1871) was a lawyer from Ryfylke in the western part of Norway. He was appointed professor in 1834. In 1827, Hjelm was given the assignment to draft a Norwegian civil code. This project was given up by the government, but Hjelm finished his work and published the draft in 1845-1846. Hjelm was later
} 
However, the commission deviated from these sources on many issues. The transmittal letter also referred to "what could be found of importance in foreign legislation". 39 There are references to a variety of foreign legislation, first and foremost the Austrian Civil Code of 1811, the French Code Civil of 1804 and the Prussian Allgemeine Landrecht of 1794. There are also references to Sardinian, Sicilian, Dutch, English and American law, not to mention the revised Swedish Inheritance Code, sanctioned by the Swedish king on 19 May 1845.

Regarding the question of equal inheritance rights for men and women, there was - in addition to the general remarks from the commission - a separate appendix summing up the major arguments for and against equal inheritance rights. ${ }^{40}$

Inspired by the leading civil codes of Europe and Winter Hjelm's draft of a Norwegian civil code ${ }^{41}$ gender equality was established in section 9 of the draft: Between co-heirs, the gender difference has no relevance, unless otherwise decided". And "otherwise" was decided in the proposed transitional provisions in section 144. The proposed transitional provision stated that if there was a son or descendant of a son born before the new act entered into force, the old provisions in Christian V's Norwegian Law Code 5-2-29 should still apply, so that each estate involving such an heir should be treated according to the old provision on "the brother's share". However, the testator should have the power to decide through a will that his heirs were given an equal share, even in these cases. ${ }^{42}$

appointed a Supreme Court Judge. He was the brother-in-law of the leader of the Inheritance law commission, Peder Carl Lasson. He was also a member of the Norwegian Academy of Science and Letters. See more detail on Hjelm's draft in Ola Mestad, "Claus Winter Hjelms lovboksarbeid: samfunnsordning og regulert kontraktsfridom," in Kodifikasjon og konstitusjon. Grunnloven § 94's krav til lovbøker i norsk historie, ed. Dag Michalsen and Hilde Sandvik (Oslo: Pax Forlag, 2013, 196-215.

${ }^{39}$ Draft 18472.

${ }^{40}$ Draft 18472 and 144-57.

${ }^{41}$ Claus Winter Hjelm, Udkast til almindelig borgerlig Lovbog ([Christiania], $1846 \S 330$.

${ }^{42}$ See Draft 184716. 
The specific provisions regarding holders of residence rights in sections 11 and 12 would, in practice, also imply a privilege for male heirs, as the allodial right legislation gave preference to male heirs.

The commission's draft proposed equal inheritance rights, but extended freedom of testation and extended rights for the oldest son - the holder of the residence right.

Although they belonged to the class of senior civil servants, the members of the Inheritance Law Commission were quite liberal. Lasson may have been influenced by his more radical brother-in-law, Claus Winter Hjelm. And Collett may have been influenced by his wife, the feminist writer Camilla Collet. When Mr Collett elaborated on the inheritance law, Mrs Collet wrote her novel "The Governor's Daughters". ${ }^{43}$ The novel is a love story with an unhappy ending. But the underlying theme is a critique of the nineteenth century ideal of womanhood that suggests they should be modest, they should not speak publicly, they should not engage in higher education and they should concentrate on their role as housewife and mother. The novel also criticizes the practice of marriages of convenience.

The proposal from the Inheritance Law Commission was at first glance a genderneutral proposal, but the transitional provisions and the specific provisions regarding holders of residence rights were major concessions to the conservatives.

\section{The Process within the Ministry of Justice and the Cabinet}

\footnotetext{
${ }^{43}$ The novel was published in two parts in 1854 and 1855.
} 
Equal inheritance rights were discussed thoroughly in the commission's proposal, ${ }^{44}$ but the Minister of Justice, Sørensen, ${ }^{45}$ was not convinced by the commission's arguments. ${ }^{46}$ The Commission received a letter from the Ministry of Justice in April 1849, in which it was challenged to reconsider its view on equal inheritance rights and the provisions regarding holders of residence rights. The commission remained firm in its original position on both matters. ${ }^{47}$ There was no proposal from the Cabinet to Parliament in the parliamentary session in 1848. The representatives Ueland and Mossige ${ }^{48}$ submitted the inheritance law commission's draft as a proposal to the parliament, but this proposal was not discussed by parliament in the 1848 session. ${ }^{49}$

However, the proposal by the Ministry of Justice in January 1851 prescribed equal inheritance rights and extended freedom of testation, but no extension of the rights for the holder of the residence right. The change of attitude from the Ministry of Justice, from the letter of 1849 to the proposal of 1851, was probably due to a change of Minister of Justice. The conservative Sørensen was replaced by the more radical Petersen ${ }^{50}$.

Even though the Minister of Justice was in favour of equal inheritance rights for men and women, his colleagues in the cabinet were opposed to it. The other members of the

\footnotetext{
${ }^{44}$ See Draft 1847 34-42, and the appendix pp. 144-57.

${ }^{45}$ Søren Anton Wilhelm Sørensen (1793-1853) was a lawyer from Drammen. He was one of the first to graduate from the Royal Frederik's University in Christiania (Oslo) in (1816). He practiced as a lawyer and was chosen to be prosecutor in an impeachment process against Severin Løvenskiold in 1836. He was a Member of Parliament from 1830 to 1845 . He was appointed Minister of Justice in 1848. Source: Lindstøl, Stortinget og Statsraadet, 872-73.

${ }^{46}$ Letter to the committee dated April 1849, Minister of Justice, Sørensen.

${ }^{47}$ See Stortingsforhandlingene 1851 Litra O No. 4 p. 31-41.

${ }^{48}$ Ingebret Svendsen Mossige (1812-1862) was a bailiff (later also Magistrate) and politician from Time in Rogaland on the south-western coast of Norway. He served as a Member of Parliament from 1845 to 1860. Source: Lindstøl, Stortinget og Statsraadet, 606-07.

${ }^{49}$ Stortinget Efterretninger 1836-1854, vol. 4, 1854, p. 293.

${ }^{50}$ Hans Christian Petersen (1793-1862) was a lawyer from Kristiansand on the southern coast of Norway. He graduated from the University of Copenhagen in 1814. He was a lawyer (Attorney General from 1830-1836), and he was Løvenskiold's defense attorney in the impeachment process in 1836 . He was appointed as a Provincial Governor in Kristiansand in 1837, and Minister of the Navy in 1839. Petersen served as Minister of Justice in several periods between 1845 and 1859. He also served as a minister in the Stockholm delegation of the Norwegian cabinet between 1840 and 1856. From 1959 to 1861, Petersen was the Prime Minister. Sources: Lindstøl, Stortinget og Statsraadet, 997; Store norske leksikon (www.snl.no) and www.wikipedia.no.
} 
cabinet, Viceroy Løvenskiold and the ministers Vogt,${ }^{51}$ Stang, ${ }^{52}$ Riddervold,${ }^{53}$ Erichsen,${ }^{54}$

Sylow ${ }^{55}$ and Bretteville, ${ }^{56}$ accepted equal inheritance rights for collaterals of both genders, but

they rejected equal inheritance rights in the line of descendants. However, parents and other

ascendants should be given the opportunity to provide equal inheritance rights in a will. Thus, the proposal from the cabinet to Parliament of February 1851 was based on unequal

inheritance shares in the descendant line and extended freedom of testation. ${ }^{57}$

The Cabinet's strategy was conservative. Status quo should be kept. However, some

concessions to liberal views were given via equal inheritance rights in the collateral lines and

${ }^{51}$ Jørgen Herman Vogt (1784-1862) was a lawyer and politician from Drammen. He graduated from the University of Copenhagen in 1806. Vogt held many important offices in the Norwegian administration from 1814 onwards. In the period 1825 to 1858 , Vogt held various offices as a minister (Prime Minister from 1856 to 1858). The only Ministry he did not lead during these years was the Ministry of the Navy. Politically, Vogt was liberal-conservative. He was in favour of cautious progress. He led the commission drafting the criminal code of 1842. Sources: Lindstøl, Stortinget og Statsraadet, 1005-1006, and Paul Thynes, "Jørgen Herman Vogt," Norsk biografisk leksikon (www.snl.no).

${ }^{52}$ Frederik Stang (1808-1884) was a lawyer and politician from Stavanger on the south-western coast of Norway. He graduated in 1828 and became associate professor in 1831, at merely twenty-three years old. His works on constitutional law was very influential. He was a member of various law commissions, and he was appointed Attorney General in 1837. He was defense attorney for Jørgen Herman Vogt in an impeachment process in 1845, where Vogt was acquitted. Immediately after this process, Stang was appointed Minister of the Interior. He also held other positions in the cabinet, for example, Prime Minister from 1873 to 1880. Stang was an economic liberalist, but in line with his close friend Anton Martin Schweigaard, he rejected the 'laissez-faire policy'. His moral views were more conservative. Stang was an active force in the industrial revolution of Norway. He was also concerned about the agricultural sector and initiated the College of Agricultural Engineering in 1854. Neither Frederik Stang nor Anton Martin Schweigaard became members of political parties. They were already dead or retired from politics when the first political parties were established in 1884 . However, the founders of the conservative party Høyre (right) were Schweigaard's and Stang's sons Christian Homann Schweigaard and Emil Stang.

${ }^{53}$ Hans Riddervold (1795-1876) was a theologian and politician from Åsgårdstrand by the Oslo fjord. He was a priest in various parishes before he became the Bishop of Trondheim in 1843. He was a Member of Parliament from 1827 to 1848 , when he was appointed Minister of the Church. In his parliamentary work, Riddervold served as president several times. Source: Lindstøl, Stortinget og Statsraadet, 712-13.

${ }^{54}$ Ole Wilhelm Erichsen (1793-1862) was a naval officer, born in Copenhagen, but he lived most of his life at Sem near Horten by the Oslo fjord. Erichsen was Minster of the Navy from 1848. Source: Lindstøl, Stortinget og Statsraadet, 984.

${ }^{55}$ Thomas Edvard von Westen Sylow (1792 - 1875) was an army officer born in Snåsa in Trondheims Amt. Sylow was Minister of the Army from 1848 to 1854. Source: Lindstøl, Stortinget og Statsraadet, 1003.

${ }^{56}$ Christian Zetlitz Bretteville (1800-1871) was a lawyer and politician from Stavanger. His family was originally of the French nobility. Bretteville held several offices as senior officer in the central administration before he was appointed Minister of Finance in 1850. He was later transferred to the Ministry of the Interior, where he served until his death. Brettville was also the mayor of Christiania (Oslo) in 1842. Sources: Lindstøl, Stortinget og Statsraadet, 712-13, and Paul Thyness, "Christian Bretteville," Norsk biografisk leksikon (www.snl.no).

57 The proposal from the Cabinet was based on the Danish Inheritance decree of 21 May 1845, section 2. Equal inheritance rights for men and women were enforced in Denmark by an amendment to the Inheritance decree of 29 December 1857. The Danish process is analysed in Vogt, “'Thi intet er naturligere'," 647-74. 
increased freedom of testation. Before the parliamentary discussion in 1851, there was a strange situation with diverging proposals from the Cabinet and from the Ministry of Justice.

\section{The Parliamentary Debate in 1851}

The proposal from the Cabinet of February 1851 was dispatched to the Norwegian Parliament (Stortinget). The proposal was discussed in Parliament's Committee for Judicial Affairs, No.

1. The committee was in favour of equal inheritance rights - in line with the Inheritance Law Commission and the Ministry of Justice:

The reasons for equal inheritance rights for sons and daughters - reasons that stems from the nature of the reverence that binds parents and children together and which at least partly must be seen as the very basis of inheritance law - are in themselves powerful, and the principle of equal rights to a such extent consistent with a sound concept of natural human rights, that it would take positive and exceptionally important counter-arguments to alter it. ${ }^{58}$

There were counter-arguments, but the counter-arguments were not considered weighty enough to keep the unjust rule in Norwegian Law Code 1687 5-2-29. The counter-arguments were based on agricultural and business policy considerations. To ease the disadvantages for farmers and owners of businesses, the committee had two solutions: first, to increase the freedom of testation for testators leaving descendants, and second, to make it possible for

\footnotetext{
${ }^{58}$ Stortingsforhandlingene 18518 D Litra B no. 4, p. 350.
} 
owners of substantial factories or other substantial enterprises to testate the business to specific heirs with reasonable compensation to the others heirs. However, the wills from the business owners should be subject to the government's approval. ${ }^{59}$

The committee could not follow the Ministry of Justice on the proposed amendments to the rights for holders of residence rights. To improve the right of primogeniture for the holder of the residence right would contrast sharply with the principle of equal inheritance rights. ${ }^{60}$

The committee's proposal was dispatched to the First Chamber of Parliament (Odelstinget). ${ }^{61}$ The provision on equal inheritance rights was heavily debated. Schweigaard was the leading opponent. He argued for the Cabinet's preferred solution - to leave the question of equal inheritance rights to the parents. The parents should have the ability to provide equal rights to their children in a will, but the default rule should, in his opinion, still be a double share for sons. ${ }^{62}$ Thus, legal practice would show whether the people would embrace the new principle or whether they would keep to the old. ${ }^{63}$ Schweigaard's attitude may be inspired by the doctrine of Savigny of law as a historical process. ${ }^{64}$ However, Schweigaard was probably aware of the fact that wills were almost never used in Norway. ${ }^{65}$ The default rule would thus be of fundamental importance. Schweigaard's main concern was the need for flexible succession in family enterprises.

\footnotetext{
${ }^{59}$ See section 39 of the proposal, Stortingsforhandlingene 1851 8D Litra B no. 4, p. 361. The provision is inspired by section 42 in the expert committee's proposal (see Draft 1847 6).

${ }^{60}$ Stortingsforhandlingene 18518 D Litra B no. 4, p. 352.

${ }^{61}$ Stortingsforhandlingene 18518 D Litra B no. 4.

${ }^{62}$ Storthinget Efterretninger 1836-1854, vol. 4, 1854, p. 632.

${ }^{63}$ Storthinget Efterretninger 1836-1854, vol. 4, 1854, p. 633.

${ }^{64}$ Friedrich Carl von Savigny, Vom Beruf unserer Zeit für Gesetzgebung und Rechtswissenschaft (Heidelberg: Mohr und Zimmer, 1814).

${ }^{65}$ See Inger Hilde Killerud, Jordisk gods - Arv, kjønn og familiestrategi i norske testamenter 1810-1854 (Oslo: University of Oslo, 2006), 59.
} 
The proponents of equal inheritance rights represented the majority in the First

Chamber. The members Ueland and Motzfeldt ${ }^{66}$ argued strongly in favour of equal inheritance rights. Sverdrup toned down the agricultural consideration. The inheritance act should apply to all citizens. "The peasants and the Nation are not the same." $" 67$

It was of course true that the nation and the peasant were not the same. However, around one-half of the population were engaged in the agricultural sector around 1850. The number of farm units was about 110,000 in 1850 in a population of about 1.4 million people. ${ }^{68}$ And many people, who were not engaged in the agricultural sector themselves, were heirs of farmers. Thus, the inheritance regulations applicable to agricultural property were of major importance to society as a whole.

The bill was passed by the First Chamber on 1 August 1851 . The bill was passed by the Second Chamber of Parliament (Lagtinget) on 5 August 1851. A member of the Second Chamber, Customs Inspector Schydtz, proposed that section 8 of the bill should be replaced with the original section 8 in the proposal from the Cabinet, but his motion was voted down, only two voted against the motion. ${ }^{69}$

The legislative decision from the Norwegian Parliament in August 1851 prescribed equal inheritance rights, extended freedom of testation, but no extension of the rights for the holder of the residence right.

\footnotetext{
${ }^{66}$ Ulrik Anton Motzfeldt (1807-1865) was a lawyer and professor born in the Danish colony of St Thomas in the West Indies. Motzfeldt graduated from the University in Oslo in 1826 and was appointed associate professor in 1829 at the age of twenty-two. He was acting professor from 1834 and appointed professor from 1839. Motzfeldt became an extraordinary Supreme Court Judge in 1839 and a full-time, appointed Supreme Court Judge from 1842. He served as a judge in the Supreme Court until his death. Motzfeldt was a Member of Parliament from 1851 to 1863 . He served in a long series of law commissions. Sources: Lindstøl, Stortinget og Statsraadet, 610, and Paul Thyness, "Ulrik Motzfeldt," Norsk biografisk leksikon (www.snl.no).

${ }^{67}$ Storthinget Efterretninger 1836-1854, vol. 4, 1854, p. 632.

${ }^{68}$ Sigurd Rysstad, "De lange linjer - Forelesninger om norsk jordbruk 1850-2013," https://athene.nmbu.no/emner/pub/ECN260/260Litteratur/SR 260_LP historie sept 2013.pdf ${ }^{69}$ Stortingsforhandlingerne 1851, vol. 9, pp. 142 and 196.
} 
However, the Cabinet advised King Oscar I not to sanction the Inheritance Act, and the King followed the advice. In the resolution of 24 September 1851, doubts were raised about changing the old rule on division between descendants and the fear of deteriorating conditions for holders of residence rights and parcelling of agricultural property. Parliament should have the opportunity to reconsider this question of profound importance to family life and the civil society. ${ }^{70}$ The conservative Cabinet of Viceroy Løvenskiold would not surrender their values, even when their proposals were turned down by Parliament.

\section{New Proposal from the Cabinet}

There was a new proposal from the Cabinet in December 1853. It provided unequal shares for male and female heirs in the descendant line, and extended freedom of testation in order to provide for equal rights in a will. The proposal was presented by the new Minister of Justice. The troublesome Petersen was moved to the Norwegian cabinet in Stockholm and replaced with the more conservative Vogt. Except for unequal shares for male and female heirs in the descendant line, the proposal was in line with the parliamentary decision of 1851 . The conservative Cabinet under Løvenskiold hoped to convince Parliament that the time was not ready for equal inheritance shares in the descendant line.

\section{The Parliamentary Debate in 1854}

The revised proposal was discussed in the parliament's Committee for Judicial Affairs No. 1. This committee proposed a revised bill to the First Chamber of Parliament (Odelstinget). ${ }^{71}$

\footnotetext{
${ }^{70}$ Stortinget Efterretninger 1836 - 1854, vol. 3, 1851, p. 630.

${ }^{71}$ Stortingsforhandlingene 1854,8 D, p. $37-54$ (Indstill. O. no. 15).
} 
The majority of the committee found it incontestable that justice and fairness demanded equal inheritance rights, and that these causes were even stronger in the descendant line than in the collateral lines. ${ }^{72}$ The majority was not convinced that equal rights would lead to more parcelling of agricultural property. In praxis, succession of agricultural property was solved by inter vivos transactions from the farmer to his oldest son. In cases were the transaction was made after the old farmer's death, the assessment of the property was usually favourable to the holder of the residence right. And unequal inheritance shares were of little help for the oldest son in cases where there were only sons or where there were a large number of heirs. ${ }^{73}$ Further, it was argued that too many allowances could not be made to one kind of citizen - the farmers. The well-being of all citizens should be taken into consideration. ${ }^{74}$

The majority admitted that the proposal from the Cabinet providing testators the ability to give their descendants of both genders equal inheritance shares via will would be an improvement for female heirs. But the most fair and just principle should be the basis for the default regulations. A will should only be the tool of choice to deviate from the principle of equality. ${ }^{75}$

The committee minority's starting point was that unequal inheritance shares were deeply rooted in Norwegian inheritance law. From the minority's point of view, the establishment of a table of heirs was not a matter of natural law. It was based on policy consideration. It could be more or less rational or suitable to meet the needs of society, but it was not given by nature. ${ }^{76}$ The minority put more weight into freedom of testation. If the citizens used their freedom of testation in order to provide equal inheritance rights for all their children, irrespective of gender, this praxis could lead to a mandatory rule of equal inheritance

\footnotetext{
${ }^{72}$ Stortingsforhandlingene 1854,8 D, p. 38.

${ }^{73}$ Stortingsforhandlingene 1854,8 D, p. 39.

${ }^{74}$ Stortingsforhandlingene 1854,8 D, p. 40.

${ }^{75}$ Stortingsforhandlingene 1854, 8 D, p. 40.

${ }^{76}$ Stortingsforhandlingene 1854,8 D, p. 40.
} 
rights. ${ }^{77}$ The minority's arguments were a combination of conservatism in favour of the old system, liberalism in favour of extended freedom of testation, and pragmatism by favouring business policy considerations and rejecting principles of natural law. ${ }^{78}$

The first reading in the First Chamber in April 1854 started with a proposal from Sverdrup, a proponent of equal inheritance shares, to postpone the case. Sverdrup's proposal was turned down. ${ }^{79}$

Schweigaard argued strongly against equal inheritance rights even in the 1854 session. He was in favour of extended freedom of testation, but he assumed that most testators would prefer double shares for male descendants as the default rule. He argued that giving equal rights to all children would essentially make the children's rights stronger than their parents' rights. The testator should be entitled to peaceful enjoyment of his possessions. Schweigaard was not convinced by the argument that equality between the genders was the default rule in most countries. He argued that most countries were based on Roman law, and that wills are extensively used in Roman law. ${ }^{80}$ Schweigaard proposed an amendment to the provision on the forced share in case Parliament voted for equal inheritance rights. The testator should then be able to provide double shares for male heirs through a will. ${ }^{81}$

The proponent, Mossige, replied to Schweigaard's arguments that the voting in the 1851 parliamentary discussion had shown that most people favoured equal inheritance shares. Mossige could not accept an unlimited freedom of testation. He found it necessary to limit the freedom of testation in order to protect the testator's family. ${ }^{82}$ Sverdrup added to Mossige's

\footnotetext{
${ }^{77}$ Stortingsforhandlingene 1854,8 D, p. 41.

78 The leading opponent, Schweigaard, is described as a pragmatic character; see Sverre Blandhol, Nordisk rettspragmatisme - Savigny, Ørsted og Schweigaard (Copenhagen: Jurist- og Økonomforbundets forlag, 2005).

${ }^{79}$ Stortingsforhandlingene 1854. Odelsthinget, p. 113.

${ }^{80}$ Stortinget Efterretninger 1836-1854, vol. 4, 1854, pp. 296-97.

${ }^{81}$ Stortinget Efterretninger 1836-1854, vol. 4, 1854, p. 297.

${ }^{82}$ Stortinget Efterretninger 1836-1854, vol. 4, 1854, p. 297.
} 
argument that no country admitted unlimited freedom of testation. The freedom of disposal of one's property has always been limited in the field of family law. All countries secure the descendants with a forced share. Historically, he argued, there had been no freedom of testation, but a transfer of all the deceased's assets to his descendants. Sverdrup concluded his argument by emphasizing equal inheritance shares for male and female heirs as one of the greatest achievements of the French Revolution. ${ }^{83}$ Even the leading farmer Ueland was in favour of equal inheritance shares. He assumed that double shares for male heirs had limited significance for succession of agricultural property. ${ }^{84}$

At the end of the discussion, Schweigaard wanted to correct some misunderstandings about his views. He was not in favour of total freedom of testation. He had never meant that unequal inheritance shares were natural, but unequal sharing was the "natural interpretation of the testator's will". The difference between his view and his opponents view was that "he gave the interest of the parents' wishes precedence over the interest of displeased children". 85

The First Chamber turned down the proposal from the Cabinet regarding unequal shares in the descendant line and instead voted for equal shares following the proposal from the majority of the Committee for Judicial Affairs No. 1. However, the testator should be able to provide double shares for male heirs according to Schweigaard's alternative proposal.

The discussion in the Second Chamber was also heated. Schydtz argued that women were less in need of inheritance than men. ${ }^{86} \mathrm{Olsen}^{87}$ disagreed. He also opposed

\footnotetext{
${ }^{83}$ Stortinget Efterretninger 1836-1854, vol. 4, 1854, p. 298.

${ }^{84}$ Stortinget Efterretninger 1836-1854, vol. 4, 1854, p. 298.

${ }^{85}$ Stortinget Efterretninger 1836-1854, vol. 4, 1854, p. 299.

${ }^{86}$ Stortinget Efterretninger 1836-1854, vol. 4, 1854, p. 300.

${ }^{87}$ Rolf Olsen (1818-1864) was a lawyer from Ris $\varnothing \mathrm{r}$ on the southern coast of Norway. He practiced as a lawyer before he became a District Judge in Gauldal near Trondheim in 1963. Olsen was a Member of Parliament from 1854 to 1864. Source: Lindstøl, Stortinget og Statsraadet, 668.
} 
Schweigaard's proposed amendment to the forced share provision. ${ }^{88}$ Daae ${ }^{89}$ would not deny that equality between the genders was a just and fair principle. But his concern was agricultural property. He illustrated his concern with the following question: "If a dress is jointly inherited, shall each heir have a part of it?"90 He argued that the same problem appears in the succession of small farms. It must either be parcelled into small units unable to breadfeed their owners, or be transferred undivided to one of the heirs. He feared that the farmers could be reduced to a class of proletarians..$^{91}$

The result of the first reading in the Second Chamber (Lagtinget) in May 1854 was that there should be equal shares, without it being possible to provide double shares for sons. The second reading in the First Chamber in May 1854 accepted the changes suggested by the Second Chamber. ${ }^{92}$ Finally, the act was sanctioned by King Oscar I on 31 July $1854 . .^{93}$

It seems like most of the debate in 1854 revolved around the extent of freedom of testation and to what extent increased freedom of testation was necessary in order to keep family property together. The differing view on what was the most fair and reasonable distribution among the heirs through statutory law was important, but some of the opponents of equal shares - especially Schweigaard - were more focused on the law of wills. It seems that the representatives from the agricultural sector, like Ueland, were confident that transfer of real estate from one generation to the next was done through inter vivos dispositions in accordance with tradition for inheritance strategies among farmers, whereas the aristocrats and bourgeoisie Members of Parliament, who were more familiar with wills, saw freedom of

\footnotetext{
${ }^{88}$ Stortinget Efterretninger 1836-1854, vol. 4, 1854, p. 301.

${ }^{89}$ Ludvig Kristensen Daae (1809-1877) was a historian from Saltdalen in the northern part of Norway. Daae had several years as a teacher combined with public positions, for example as a state archivist, before he was appointed associate professor in 1862 and professor in 1866. He was a member of several sessions of Parliament between 1842 and 1873. Source: Lindstøl, Stortinget og Statsraadet, 1785.

${ }^{90}$ Stortinget Efterretninger 1836-1854, vol. 4, 1854. p. 301.

${ }^{91}$ See more in detail on his views in Draft 1847 154-55.

${ }^{92}$ Stortinget Efterretninger 1836-1854, vol. 4, 1854, p. 302.

${ }^{93}$ Referred to in Stortingsforhandlingene 1854. 9 D Odelsthinget, p. 151.
} 
testation as crucial for their inheritance strategies. This may imply that the two sides not necessarily disagreed on what was the best solution for the transfer of family businesses, but that their different social background influenced theirs preferences.

\section{Transitional Provisions}

The Inheritance Law Commission proposed that the old provision in Norwegian Law Code of 1687 5-2-29 should still apply for descendants born before the new act entered into force. ${ }^{94}$ The commission did not want the new principle to have retroactive effect. However, testators should have the possibility to provide equal inheritance shares through a will.

The Cabinet and the Committee for Judicial Affairs No. 1 were both aware of the need for transitional provisions, but they did not find it necessary to have a transitional period of such a long and indefinite period as proposed by the Inheritance Law Commission. The Cabinet proposed a transitionary period of ten years, whereas the plurality of the Committee for Judicial Affairs No. 1 would limit the transitional period to five years. ${ }^{95}$

There was some discussion in Parliament on the transitional provisions. There was consensus about the transitional provision of five years before the act could be applicable for descendants born before the act entered into force. There was more discussion on the transitional provisions regarding freedom of testation. All agreed that the testator should be able to provide equal inheritance shares via will, even if there were male descendants born before the act entered into force. Such wills had been confirmed unconditionally by the authorities since the days of the Danish-Norwegian union, and confirmations of such wills

\footnotetext{
${ }^{94}$ Draft 1847 140-41.

${ }^{95}$ Stortingsforhandlingene 1851,8 D, p. 356.
} 
were frequently given. ${ }^{96}$ But there was more reluctance to testamentary dispositions providing unequal inheritance shares. ${ }^{97}$

The arguments from the opponents of equal shares regarding will-based unequal shares were more convincing than their arguments in favour of statute-based unequal shares. They argued for freedom of testation and against retroactive legislation. The opponents drew the longest straw in this discussion. It was stated in the act that a testator with male descendants born before the new act entered into force could provide by will that such male heirs inherited double shares compared to their female co-heirs. ${ }^{98}$ In principle, this provision could affect probate processes into the twentieth century. However, there is little trace of the use of this extended freedom of testation. ${ }^{99}$

\section{The Opponents Revenge - Amendment to the Allodial Rights Act in 1863}

The opponents of equal inheritance shares accepted the defeat. Nobody argued for reinstating unequal shares. But the opponents of equal shares had one more card to play.

From the end of the 1850 s, there was a crisis in the agrarian sector caused by a mixture of competition from grains from America and Ukraine, parcelling and the farmers being encumbered with debts. ${ }^{100}$ Some blamed the new inheritance act for the troubles in the agricultural sector. Increased freedom of testation was insufficient to keep agrarian property

\footnotetext{
${ }^{96}$ See Royal Decree of 4 July 1800, section 2. See Tage Algreen-Ussing, Haandbog i den danske Arveret, (Copenhagen: Gyldendalske Boghandling, 1855), 48-49. Even if this decree was issued during the Danish rule, it still applied. The Constitution of 1814, section 94, stated that the laws applicable in 1814 remained in force, provided that they did not come into conflict with the Constitution or with later legislation.

${ }_{97}^{97}$ Stortinget Efterretninger 1836-1854, vol. 4, 1854, p. 302.

${ }^{98}$ The Inheritance Act section 80 fourth paragraph.

${ }^{99}$ Sørsdal, Fra Broderlodd til 'billig taxt', 41-43. The same seems to have been the case in Sweden: see Maria Ågren, “'Hon skall ha min stickmaskin'. Bruket av testamenten i en region i omvandling, 1750 - 1915," in Tid och tillit. En vänbok till Eva Österberg, ed. Irene Anderson, Kenneth Johansson and Marie Lindstedt Cronberg (Stockholm: Atlantis, 2002), p. 101-21, at p. 119.

${ }^{100}$ Sørsdal, Fra Broderlodd til 'billig taxt', 45-51, and Stortingsforhandlingene 1862-63, 8 D, no. 17, p. 2.
} 
undivided, since farmers seemed reluctant to use it. ${ }^{101}$ The solution to the problem was to ease the burden for the holders of residence rights - and the holder of the residence right was the oldest son. ${ }^{102}$

In the parliamentary session in 1862 , there was a proposal from Richter ${ }^{103}$ to give the holder of the residence right a right to withhold a certain amount before the division of property between the heirs. This exemption right would ease the burden of buying out the other heirs. ${ }^{104}$ The aim was to secure a class of independent free-holding farmers. ${ }^{105}$ It was also argued that it was necessary in order to make good for the injustice new legislation had caused the farmers, namely the Allodial Rights Act of 1821 and the Inheritance Act of 1854 . The Allodial Rights Act provided an opportunity to parcel the residence into several units and the holder of the residence right had to buy out his co-heirs based on the market value of the estate. ${ }^{106}$ A deviation from the principle of market value would indirectly be to the detriment of female heirs, as the holder of the residence right was the oldest son.

Richter's proposal was not appraised by Parliament. Several Members of Parliament opposed the idea of withholding a certain sum from the estate. It was contrary to the principle of equal rights. ${ }^{107}$ Even if the majority would not support Richter's proposal, most Members of Parliament agreed that something had to be done.

\footnotetext{
${ }^{101}$ Sørsdal, Fra Broderlodd til 'billig taxt', 41-43.

${ }^{102}$ See the Allodial Rights Act of 26 June 1821, section 11.

${ }^{103}$ Ole Richter (1829-1888) was a lawyer, editor and politician from Inderøy in Trondheims Amt. He graduated from the Royal Frederik's University in Christiania (Oslo) in 1852, but carried on studying law in England. He practiced law in the Trondheim area. Richter was a Member of Parliament from 1862 to 1878. In 1878 Richter became Swedish and Norwegian Consul in London. He was appointed minister in Stockholm in in Sverdrup's Cabinet in 1884. He resigned and committed suicide in 1888 after a deep conflict with Sverdrup and his old friend Bjørnstjerne Bjørnson (the Nobel laureate in literature) had exposed his confidential and compromising letters to the public.

${ }^{104}$ Stortingsforhandlingene 1862-62, 8 D, Doc. No. 17 p. 5.

105 Sørsdal, Fra Broderlodd til 'billig taxt', 52.

${ }^{106}$ See the Allodial Rights Act of 26 June 1821 section 14 (parceling) and 19 (assessment).

107 Stortings-Tidende 1862-63, vol. 2, p. 352.
} 
And something was done. Schweigaard found a solution that was flexible enough to be acceptable for both parties. His proposal concerned the assessment of the price the holder of the residence right had to pay in order to buy out his co-heirs. Schweigaard's proposal had the following wording:

The holder of the residence right may claim the residence for the price decided by the testator in a will. If there is no such predetermined price, the price is based on a fair assessment. $^{108}$

The term 'fair assessment' is rather vague. This was an intended vagueness in order to achieve maximum flexibility. ${ }^{109}$ It could include various local customs for assessing agricultural property. In some areas a fair assessment would equal the market value, and in other areas there was a distinct 'discount' for the holder of the residence right. A 'fair assessment' would not totally disregard the principle of equality. Schweigaard's proposal was passed by Parliament and sanctioned by the king on 9 May $1863 .{ }^{110}$

Schweigaard's compromise eased the burden of the holders of residence rights. But it must be seen as a backlash for the women. The Allodial Rights Act was not yet gender-neutral and the women had to wait another hundred years until women's liberation reached the agricultural sector.

\footnotetext{
108 Stortings-Tidende 1862-63, vol. 2, p. 356 (authors translation).

${ }^{109}$ See Schweigaard's reasoning in Stortings-Tidende 1862-1863, vol. 2, pp. 355-56.

${ }^{110}$ Act on Amendments to the Legislation on Residence Right of 9 May 1863.
} 


\section{The Final Breakthrough - The Act on Allodial Rights of 1974}

Schweigaard's principle of fair assessment is still applied in the present Allodial Rights Act from 1974. ${ }^{111}$ This principle implies a slight deviation from the principle of equal treatment of all descendants. But this principle no longer implies a preference for male heirs. The present act is gender-neutral. The descendants have priority according to their age and regardless of gender. ${ }^{112}$ But of course there were transitional provisions even in the 1974 act. The new provision based on gender-neutrality did not apply to those who were born or adopted before 1 January $1965 .{ }^{113}$ In practice, the transitionary provision had the consequence that male descendants were preferred in succession of agricultural property far into the twenty-first century.

It was not without discussion that the Allodial Rights Act was made gender-neutral in 1974. During a revision of the act in 1907, gender neutrality was not even discussed. ${ }^{114}$ And even in the preparatory works from the early 1970s, there were some doubts about gender neutrality. On the one hand, it was argued that equal rights were principally correct. On the other hand, there was tradition. It was also argued that men were by nature better suited to running a farm. ${ }^{115}$ These arguments against gender-neutrality led to the quite lengthy transitional provisions in the 1974 act.

Gender-based inequality is difficult to justify from a human rights point of view. In a case from the European Court of Human Rights of 28 October 1987, Austria was held liable for breach of the European Convention on Human Rights, since Austrian regulations on succession of agricultural property made a distinction between children born in and out of

\footnotetext{
${ }^{111}$ Act on Allodial Rights of 28 June 1974, no. 58, section 56.

${ }^{112}$ Act on Allodial Rights of 28 June 1974, no. 58, sections 52 and 12.

113 Act on Allodial Rights of 28 June 1974, no. 58, section 78.

114 Rådsegn 10 frå Sivillovbokutvalet “Om odelsretten og åsetesretten,” (NOU 1972: 22), p. 62.

115 NOU 1972: 22, p. 62.
} 
wedlock. ${ }^{116}$ The Norwegian expert commission on Allodial Rights found the Norwegian transitional provision problematic from a human rights perspective. The committee proposed to repeal the transitional provision. ${ }^{117}$ The transitional provision was finally repealed in 2009. ${ }^{118}$ The repeal of this provision was one of several adjustments made to the Allodial Rights Act and other agricultural regulations. Strangely enough, the fact that this amendment was the end of a 200-year-long struggle for gender-neutral inheritance rights was not mentioned in the parliamentary debate. Maybe women's liberation had come so far that it was not worth mentioning?

\section{Conclusions}

The principle of equal inheritance shares for male and female heirs in the Inheritance Act of 1854 was an important step in the struggle for women's liberation in Norway. However, it was far from sufficient in putting women on an equal basis with men in society in general. Woman in general did not have the same legal capacity as men before $1863 .{ }^{119}$ And married women did not gain full legal capacity until $1888 .{ }^{120}$ And even after 1888 , the husband was still in charge of the entire marital joint property. It was not until 1927 that married men and women enjoyed the same right to dispose of their property. ${ }^{121}$ Even if equal inheritance shares in Norway were introduced at a late stage of history in Norway compared to other European countries, equal inheritance shares was an early step in the national development of women's liberation. The women's rights movement in Norway gained strength throughout the

\footnotetext{
${ }^{116}$ Inze v Austria (1987) 10 EHRR 394.

${ }^{117}$ NOU 2003: 26 Om odels- og åsetesretten, pp. 26-28.

118 Act 19 June 2009, no. 98.

${ }^{119}$ Act 11 April 1863, section 1.

${ }^{120}$ Act 39 June 1888, section 11.

${ }^{121}$ Act 20 May 1927, no. 1, section 7.
} 
nineteenth century, and in 1913, Norway became the second country in Europe to give women the right to vote in general elections. ${ }^{122}$

Gender neutrality regarding the takeover of agricultural property is not only a matter of inheritance law; it is to a large extent also dependent on gender equality in the work force. To a large extent, a gendered labour market still exists, even in Norway with its precedence for women being Prime Minister. Merely $11 \%$ of all nurses are male and merely $11 \%$ of all construction engineers are female. The balance is somewhat better in the agricultural sector, where the percentage of female farmers is around $25 \% .{ }^{123}$ Nevertheless, it seems like tradition is a key element in the transferring of agricultural property from one generation to the other.

It is also a paradox that it took more than 150 years for the principle of equality in inheritance law to be made fully applicable in succession of agricultural property. As the text above shows, many of the proponents of equal inheritance shares for men and woman were in fact farmers. Several proposals from the 1830s and 1840s were initiated by farmers. In the discussions of 1851 and 1854, two of the leading proponents were Ueland and Jaabæk. This positive attitude towards equal inheritance shares from the farmers may have been influenced by the farmers' knowledge that most successions in agricultural estates were made through inter vivos dispositions. And if the property was not transferred in a lifetime disposition, the residence right in the Allodial Rights Act secured the property for the oldest son anyway.

It was not until the 1974 Allodial Rights Act that the primogeniture of the oldest son was challenged. At that point, the time had come for equal rights even in the agricultural sector. At least, the time had come for future daughters of farmers to take over agricultural property. Those who grew up under the old system had to wait until 2009 before they could

\footnotetext{
122 Amendment to the Norwegian constitution of 11 June 1913. Finland was the first, in 1906.

${ }^{123}$ Employed based on gender and occupation. https://www.ssb.no/a/kortnavn/yrkeaku/tab-2012-04-26-03.html.
} 
feel the winds of change. Meanwhile, in most cases their younger brothers had taken over the property due to a fair assessment.

When the time had finally come for equal rights in the agricultural sector, the agricultural sector's role in society was diminishing. The number of farm units was about 110,000 in 1850 in a population of about 1.4 million people, and it rose to more than 200,000 at its peak in 1950 when the population reached 3.25 million. When the transitional provisions in the Allodial Act were finally repealed, in 2009, the number of farm units had decreased to below 50,000 whereas the population had reached almost 5 million. ${ }^{124}$ The agricultural sector - once the cornerstone of the national economy - is today reduced to a marginal sector heavily subsidized by the Norwegian state. The Norwegian succession law is finally genderneutral - even in the agricultural sector. Sadly, this is achieved when the agricultural sector has declined to be a marginal sector in the Norwegian society. Men still dominate the more important sectors of the national economy. The present cornerstone of the national economy is the primarily state-owned oil and gas industry. And the oil and gas industry is of course run by men. The statistics tell us that $83.3 \%$ of all chief executive officers and $87.5 \%$ of all oil and gas engineers are men. ${ }^{125}$ It seems like the laws of economy are even harder to change than the law in books.

\section{Bibliography}

Act 11 April 1863: www.lovdata.no

\footnotetext{
${ }^{124}$ Sigurd Rysstad, "De lange linjer - Forelesninger om norsk jordbruk 1850-2013," https://athene.nmbu.no/emner/pub/ECN260/260Litteratur/SR_260_LP historie_sept_2013.pdf. See also: https://www.ssb.no/jord-skog-jakt-og-fiskeri/artikler-og-publikasjoner/mange-bur-paa-gard-faerre-er-bonder. ${ }^{125}$ Employed based on gender and occupation. https://www.ssb.no/a/kortnavn/yrkeaku/tab-2012-04-26-03.html.
} 
Act 39 June 1888: www.lovdata.no

Act 20 May 1927: $\underline{\text { www.lovdata.no }}$

Act 28 June 1974, no. 58: www.lovdata.no

Act 19 June 2009, no. 98: www.lovdata.no

Algreen-Ussing, Tage, Haandbog i den danske Arveret (Copenhagen: Gyldendalske Boghandling, 1855).

Ågren, Maria, “'Hon skall ha min stickmaskin'. Bruket av testamenten i en region i omvandling, 1750 - 1915," in Tid och tillit. En vänbok till Eva Österberg, ed. Irene Anderson, Kenneth Johansson and Marie Lindstedt Cronberg (Stockholm: Atlantis, 2002), 101-21.

Blandhol, Sverre, Nordisk rettspragmatisme - Savigny, Ørsted og Schweigaard (Copenhagen: Jurist- og Økonomforbundets forlag, 2005).

Commission til at udarbeide Udkast til en Lov om Arveretten m.v. (1846), “Angaaende naadigst Proposition til Norges Riges Storthing betræffende Udfærdigelse af en Lov om Arv. Underdanigst Indstilling fra den til at udarbeide Udkast til en Lov om Arveretten m.v. ved Resolution af 7de Februar 1846 nedsatte Commission" (Christiania: 1847). [Draft from the Inheritance Act Commission, submitted to Parliament, 11 June 1847].

The Danish Laws or the Code of Christian V. Translated for the Use of the English Inhabitants of the Danish Settlements in America (London, 1756).

Hjelm, Claus Winter, Udkast til almindelig borgerlig Lovbog ([Christiania], 1846).

Inze v Austria (1987), 10 EHRR 394. 
Killerud, Inger Hilde, Jordisk gods - Arv, kjønn og familiestrategi i norske testamenter 18101854 (Oslo: University of Oslo, 2006).

Lindstøl, Tallak, Stortinget og Statsraadet 1814-1914 (Kristiania: Steen’ske bogtrykkeri, 1914).

Mestad, Ola, “Claus Winter Hjelms lovboksarbeid: samfunnsordning og regulert kontraktsfridom," in Kodifikasjon og konstitusjon. Grunnloven $§ 94$ 's krav til lovbøker i norsk historie, ed. Dag Michalsen and Hilde Sandvik (Oslo: Pax Forlag, 2013, 196-215.

Norsk biografisk leksikon: $\underline{w w w . s n l . n o}$

The Norwegian Constitution of 17 May 1814: www.lovdata.no

NOU 1972: 22. Norges Offenlige Utredninger. Om odelsretten og åsetesretten. Rådsegn 10 frå Sivillovbokutvalet. Universitetsforlaget, 1972.

Rysstad, Sigurd, "De lange linjer - Forelesninger om norsk jordbruk 1850-2013.” https://athene.nmbu.no/emner/pub/ECN260/260Litteratur/SR_260_LP_historie_sept_2013.pd f. See also: https://www.ssb.no/jord-skog-jakt-og-fiskeri/artikler-og-publikasjoner/mange-burpaa-gard-faerre-er-bonder

Sandvik, Hilde, and Dag Michalsen, Kodifikasjon og konstitusjon (Oslo: Pax Forlag, 2013).

Statistics Norway: $\underline{w w w . s s b . n o}$

Store norske leksikon: $\underline{\text { www.snl.no }}$

Storthinget Efterretninger, (Christiania, 1814 -).

Stortingsforhandlingene: $\underline{\text { www.stortinget.no }}$

Stortings-Tidende: $\underline{\text { www.stortinget.no }}$ 
Sørsdal, Kari, Fra Broderlodd til 'billig taxt' (1854-1863) (Oslo: Institutt for privatrett, University of Oslo, 1980).

Vogt, Helle, “"Thi Intet er naturligere og retfærdigere end Qvindekjønnets lige Arveret med Mandskjønnet'," Tidsskrift for rettsvitenskap 122 (2009): 647-74.

\section{Author Description}

John Asland is Professor of Law at the Faculty of Law, University of Oslo, Norway. His main fields of research are family law and the law of succession, and he is the author and co-author of several books on these topics. He was temporarily appointed appellate court judge during 2008-2010, and he served as secretary of the Inheritance Act Commission during 2011-2014. He is also Professor II at Inland Norway University of Applied Sciences and co-editor of Norway's leading journal on family law. He was awarded the King's gold medal for his $\mathrm{PhD}$ thesis in 2009. Asland was fellow at the Centre for Advanced Studies in Oslo 2014-2015. 